\title{
PATHOGENIC AND LETHAL EFFECTS OF THE ENTOMOPATHOGENIC NEMATODES ON THE PEACH FRUIT FLY, BACTROCERA ZONATA (SAUNDERS) AND THE CUCURBIT FRUIT FLY, DACUS CILIATUS (LOEW) (DIPTERA : TEPHRITIDAE)
}

\author{
FETOH, BADR EL-SABAH A. ${ }^{1}$, A. A. ABDEL GAWAD ${ }^{2}$, \\ F. F. SHALABY ${ }^{2}$ AND M. F. ELYME ${ }^{1}$
}

1. Plant Protection Research Institute, ARC, Dokki, Giza

2. Moshtohour Agriculture Faculty, Banha University

(Manuscript received 24 August 2010)

\begin{abstract}
Laboratory experiments were performed to evaluate the pathogenic and lethal effects of the entomopathogenic nematodes $\mathrm{Hb}$ (Heterorhabditis bacteriophora Poinar) and Sc (Steinernema carpocapsae All strains) on the full grown larvae, newly formed pupae and seven days old adults of the peach fruit fly, Bactrocera zonata and the cucurbit fly, Dacus ciliatus. Mortality rates ranged from 9.3 to $42.7 \%, 12.7$ to $52.3 \%$ for the full grown larvae of both B. zonata and $D$. ciliatus treated by Sc nematode, respectively, and from 67.3 to $100 \%$, from 46.3 to $100 \%$ for the full grown larvae of both $B$. zonata and $D$. ciliatus treated by $\mathrm{Hb}$ nematode, respectively, whereas mortality rates of pupae ranged from 2.7 to $32.7 \%$ for the pupae of $B$. zonata treated by Sc nematode, from 1.7 to $23.3 \%$ for the pupae of $D$. ciliatus treated by Sc nematode, from 12.7 to $51.7 \%$ for the pupae of $B$. zonata treated by $\mathrm{Hb}$ nematode and from 6.3 to $39.3 \%$ for the pupae of $B$. zonata treated by $\mathrm{Hb}$ nematode. Furthermore, the mortality rates varied from 35.0 to $78.7 \%, 7.7$ to $50.3 \%$ for 7 days old adults of both $B$. zonata and $D$. ciliatus treated by Sc nematode, respectively, 41.7 to 90.3 and 17.0 to $67.7 \%$ for 7 days old adults both B. zonata and $D$. ciliatus treated by $\mathrm{Hb}$ nematode, respectively. $\mathrm{LC}_{50}$ and $\mathrm{LC}_{90}$ values were $325.3,286.2,1718.6$ and $1650.0 \mathrm{IJs} / \mathrm{cm}^{2}$ for larvae of $B$. zonata and $D$. ciliatus treated with Sc nematode, 28.8, 56.7, 167.2 and $156.1 \mathrm{IJs} / \mathrm{cm}^{2}$ for larvae of $B$. zonata and $D$. ciliatus treated with $\mathrm{Hb}$ nematode, 540.2, 447.4, 1785.4 and $2009.8 \mathrm{IJs} /$ $\mathrm{cm}^{2}$ for pupae of $B$. zonata and $D$. ciliatus treated with $\mathrm{Sc}$ nematode, 235.0, 420.8, 1167.0 and $1941.5 \mathrm{IJs} / \mathrm{cm}^{2}$ for pupae of $B$. zonata and $D$. ciliatus treated with $\mathrm{Hb}$ nematode, 116.8, 261.6, 319.3 and $375.0 \mathrm{IJs} / \mathrm{cm}^{2}$ for adults of $B$. zonata and D. ciliatus treated with Sc nematode and 77.3, 196.7, 290.8 and 253.7 IJs/ $\mathrm{cm}^{2}$ for adults of $B$. zonata and $D$. ciliatus treated with $\mathrm{Hb}$ nematode, respectively. From the obtained results we can conclude that the entomopathogenic nematodes: $\mathrm{Hb}$ Heterorhabditis bacteriophora Poinar) and Sc (Steinernema carpocapsae All strains) were effective on the different stages of $B$. zonata and $D$. ciliatus, $\mathrm{Hb}$ nematode was more virulent than Sc nematode and the larvae and adults of $B$. zonata and $D$. ciliatus were more susceptible to the nematodes infection than the pupae.
\end{abstract}




\section{INTRODUCTION}

The peach fruit fly, Bactrocera zonata (Saunders) is one of the most harmful insect species of family Tephritidae. It is a polyphagous species, but is particularly a pest of peach, mango and guava. It also, infests some vegetables as a secondary pest. It is a significant pest in many countries such as India, Pakistan, Indonesia, SriLanka, Vietnam, Thailand, Burma, Nepal and Bangladesh. Publications from Pakistan show that it is possibly more important than B. dorsalis (Kapoor, 1993). In Egypt, B. zonata is now established and widespread. In Egypt, the cucurbit fly, Dacus ciliatus (Loew) was recorded for the first time by Azab and Kira (1954) as a serious pest on cucurbitaceous fruits, continued till 1980 and disappeared, then reappeared again after nearly 23 years (Fetoh, 2006). Current control methods of these pests rely heavily on the aerial application of malathion, bait sprays, or ground cover sprays of potent organophosphorus pesticides. These methods have a negative impact on the environment, and specifically on the phytoparasitic populations of beneficial organisms. Thus, environmentally friendly methods of control are much in need (Roessler, 1989). Entomopathogenic nematodes in the families Steinernematidae and Heterorhabditidae have been shown to be pathogenic to a wide range of agricultural important pests and are useful alternatives to chemical insecticides for insect control (Gaugler and Kaya, 1990). The infective juveniles of entomopathogenic nematodes enter their host through natural openings (Steinernematidae and Heterorhabditidae) and rarely through the direct penetration of host cuticle (Heterorhabditidae) (Shapiro and Lewis 1999). Entomopathogenic nematodes kill their hosts though the association with the mutualistic bacteria, i.e. Xenorhabdus spp. in steinernematids and Photorhabdus spp. in heterorhabitids. These mutualistic bacteria release toxins or metabolites or proteases that finally kill the host within 2-3 days. The aim of the present work is estimating the pathogenic and lethal effects of the entomopathogenic nematodes, $\mathrm{Hb}$ (Heterorhabditis bacteriophora Poinar) and Sc (Steinernema carpocapsae All strains) on different stages of the $B$. zonata and $D$. ciliatus under the laboratory conditions.

\section{MATERIALS AND METHODS}

A culture of adult flies of $B$. zonata and $D$. ciliatus was maintained in the laboratory in Vegetable, Medicinal, Ornamental and Aromatic Insect Pests Researches Department, Plant Protection Research Institute, at $25 \pm 2{ }^{\circ} \mathrm{C}, 80 \pm 10 \%$ R.H. and L12:D12 photoperiod. Larvae of $B$. zonata were reared on bran diet described by Tanaka et al., (1969). Larvae of $D$. ciliatus were reared on small marrow fruits 
according to Fetoh (2006). Pupae were obtained by sieving the sandy layers at the bottom of rearing containers.

The nematodes, $\mathrm{Hb}$ (Heterorhabditis bacteriophora Poinar) and Sc (Steinernema carpocapsae All strains) were reared and multiplied on the greater wax moth larvae, Galleria mellonella L. according to the method described by Kaya and Stock (1997).

Nematode hosts exposure were carried out in Petri dishes $(10 \mathrm{~cm})$ containing 30 gm of clean and dry sand. Different concentrations of EPN were prepared at: 50, 100, 150, 200 and $250 \mathrm{IJs} / \mathrm{cm} 2$ of both nematodes species and added to Petri dishes. 100 of full grown larvae (third or popped larval instar) and 100 of newly formed pupae were introduced to nematodes. Each concentration was replicated three times for each concentration for each insect species. Control test (untreated) was carried out at the same time in parallel to the nematodes tests.

Also, 100 adult flies (7 days old) were used for each concentration of the EPN in sugary solution put in small glassy vials $(10 \mathrm{ml})$ containing cotton wick piece, as a source of food, drink and nematode infection. Adult flies were put in large glassy pots $(250 \mathrm{ml})$, covered with piece of fabric and then tied by elastic threads. Control treatment had only sugary solution. Also, each concentration was replicated three times for each insect species. Control test (untreated) was carried out at the same time in parallel to the nematodes tests according to Fetoh and El-Gendi (2006).

All tests were observed daily to detect the mortality of exposed larvae, pupae and adults were recorded till 7days.

\section{Data analysis}

The mortality resulted from the effect of EPN was calculated and corrected according to Abbott's formula (Abbott, 1925). Log- probity lines and relative toxicity for different concentrations were obtained by Finney (1971) using a detected software program. Duncan's multiple range test (Duncan, 1955) was used to differentiate between the means of mortalities.

\section{RESULTS AND DISCUSSION}

\section{Efficiency of the entomopathogenic nematodes (EPN) on different stages of PFF and CFF}

\section{On the full grown larvae (Leaping larvae or $3^{\text {rd }}$ instar larvae)}

The obtained data in Table (1) indicate that the both used EPN were effective and virulent on the full grown larvae of PFF and CFF, while Sc nematode was lower virulence than $\mathrm{Hb}$ nematode on the full grown larvae of PFF and CFF.

The means mortality percent were increased in parallel manner with the increasing in EPN concentration $\left(50,100,150,200,250 \mathrm{IJs} / \mathrm{cm}^{2}\right)$, means mortality percent 
were ranged from 9.3 to $37.7 \%$, from 12.7 to $52.3 \%$, for the full grown larvae of PFF and CFF, respectively. The means mortality percent were : 9.3, 14.7, 25.0, 37.7 and $42.7 \%$, respectively for PFF larvae treated with Sc nematode. The means mortality percent were: $12.7,20.0,26.7,37.7$ and $52.3 \%$, respectively, for CFF larvae treated with Sc nematode.

$\mathrm{Hb}$ nematode showed the same effect and the means mortality percent were ranged from 67.3 to $100.0 \%$ for PFF larvae and from 46.3 to $100.0 \%$ for CFF larvae. The means mortality percent were: $67.3,79.7,86.3,94.7$ and $100.0 \%$ for PFF larvae treated by $\mathrm{Hb}$ nematode. The means mortality percent were: 46.3, 72.7, $86.7,98.0$ and $100.0 \%$ for CFF larvae treated by $\mathrm{Hb}$ nematode, respectively. Moreover, $\mathrm{Hb}$ nematode was highly virulent than $\mathrm{Sc}$ nematode on the full grown larvae of both tested flies (PFF and CFF). The larvae of CFF were more susceptible to $\mathrm{Sc}$ and $\mathrm{Hb}$ nematodes than the larvae of PFF.

The calculated $\mathrm{LC}_{50}$ was $325.3 \mathrm{and} 286.2 \mathrm{Ijs} / \mathrm{cm}^{2}$ for Sc nematode on the larvae of PFF and CFF, respectively, $\mathrm{LC}_{50}$ was 28.8 and $56.7 \mathrm{Ijs} / \mathrm{cm}^{2}$ for $\mathrm{Hb}$ nematode on the larvae of PFF and CFF, respectively, $\mathrm{LC}_{90}$ was 1718.6 and $1650 \mathrm{Ijs} / \mathrm{cm}^{2}$ for Sc nematode on the larvae of PFF and CFF, respectively, and LC 90 was 167.2 and $156.1 \mathrm{Ijs} / \mathrm{cm}^{2}$ for $\mathrm{Hb}$ nematode on the larvae of PFF and CFF, respectively, (Table 4 and Figs 1\&2).

\section{On the newly formed pupae:}

The results in Table (2) revealed that the both used EPN were effective and virulent on the newly formed pupae of PFF and CFF, while Sc nematode was lower virulence than $\mathrm{Hb}$ nematode on the pupae of PFF and CFF.

The means mortality percent were increased in ascending manner with the increasing in EPN concentration (50,100,150, 200, $\left.250 \mathrm{IJs} / \mathrm{cm}^{2}\right)$, means mortality percent were ranged from 2.7 to $32.7 \%$, from 1.7 to $23.3 \%$, for the newly formed pupae of PFF and CFF, respectively. The means mortality percent were: 2.7, 9.0, 12.0, 21.7 and $32.7 \%$, respectively for PFF pupae treated with Sc nematode . The means mortality percent were: $1.7,4.0,9.0,17.1$ and $23.3 \%$, respectively, for CFF pupae treated with Sc nematode.

$\mathrm{Hb}$ nematode showed the same effect and the means mortality percent were ranged from 12.7 to $51.7 \%$ for PFF pupae and from 6.3 to $39.3 \%$ for CFF pupae. The means mortality percent were: 12.7, 20.3, 35.7, 47.7 and $51.7 \%$ for PFF pupae treated by $\mathrm{Hb}$ nematode. The means mortality percent were: $6.3,8.7,14.7$, 25.0 and $39.3 \%$ for CFF pupae treated by $\mathrm{Hb}$ nematode, respectively. Moreover, $\mathrm{Hb}$ nematode was highly virulent than Sc nematode on the pupae of both tested 
flies (PFF and CFF). Pupae of PFF were more susceptible to Sc and $\mathrm{Hb}$ nematodes than the pupae of CFF.

The calculated $\mathrm{LC}_{50}$ was 540.2 and $447.4 \mathrm{Ijs} / \mathrm{cm}^{2}$ for Sc nematode on the pupae PFF and CFF, respectively, $\mathrm{LC}_{50}$ was 235.0 and $420.8 \mathrm{Ijs} / \mathrm{cm}^{2}$ for $\mathrm{Hb}$ nematode on PFF and CFF, respectively, $\mathrm{LC}_{90}$ was 1785.4 and $2009.8 \mathrm{Ij} / \mathrm{cm}^{2}$ for Sc nematode on PFF and CFF, respectively, and $\mathrm{LC}_{90}$ was 1167.0 and $1914.5 \mathrm{Ijs} / \mathrm{cm}^{2}$ for $\mathrm{Hb}$ nematode on the pupae of PFF and CFF, respectively, (Table 5and Figs 3\&4).

\section{On the adults}

The obtained data in Table (3) showed that the both used EPN were effective and virulent on the adults of PFF and CFF, while Sc nematode was lower virulence than $\mathrm{Hb}$ nematode on the adults of PFF and CFF.

The means mortality percent were increased in parallel manner with the increasing in EPN concentration $\left(50,100,150,200,250 \mathrm{IJs} / \mathrm{cm}^{2}\right)$, means mortality percent were ranged from 35.0 to $78.7 \%$ and from 7.7 to $50.3 \%$, for the adults of PFF and CFF, respectively. The means mortality percent were: 35.0, 39.7, 48.0, 62.3 and $78.7 \%$, respectively for PFF adults treated with Sc nematode. The means mortality percent were: $7.7,13.7,22.7$, and 28.3 and $50.3 \%$, respectively, for CFF adults treated with Sc nematode.

$\mathrm{Hb}$ nematode gave the same effect and the means mortality percent were ranged from 41.7 to $90.3 \%$ for PFF adults and from 17.0 to $67.7 \%$ for CFFadults. The means mortality percent were: 41.7, 51.7, 66.7, 73.3and $90.3 \%$ for PFF adults treated by $\mathrm{Hb}$ nematode. The means mortality percent were: 17.0, 25.3, 37.7, 43.7 and $67.7 \%$ for CFF adults treated by $\mathrm{Hb}$ nematode, respectively. Moreover, $\mathrm{Hb}$ nematode was highly virulent than Sc nematode on the adults of both tested flies (PFF and CFF). The adults of PFF were more susceptible to $\mathrm{Sc}$ and $\mathrm{Hb}$ nematodes than the adults of CFF.

The calculated $\mathrm{LC}_{50}$ was 116.8 and $261.6 \mathrm{IJs} / \mathrm{cm}^{2}$ for Sc nematode on the adults of PFF and CFF, respectively, $\mathrm{LC}_{50}$ was 77.3 and $196.7 \mathrm{IJs} / \mathrm{cm}^{2}$ for $\mathrm{Hb}$ nematode on the adults of PFF and CFF, respectively, $\mathrm{LC}_{90}$ was 319.3 and $375.0 \mathrm{IJs} / \mathrm{cm}^{2}$ for Sc nematode on the adults of PFF and CFF, respectively, and LC 90 was 290.8 and $235.7 \mathrm{IJs} / \mathrm{cm}^{2}$ for $\mathrm{Hb}$ nematode on the adults of PFF and CFF, respectively, (Table 6 and Figs 5\&6).

The obtained results emphasized that the entomopathogenic nematodes (EPN) could be used successfully in controlling both of PFF and CFF. Both of Sc and $\mathrm{Hb}$ nematodes were effective and virulent on the larvae and adults of PFF and CFF , while the pupae were less susceptible. This is in the same trend with Gaugler and Kaya (1990) who mentioned that EPN of genera Heterorhabditis and Steinernema 

DACUS CILIATUS (LOEW) (DIPTERA : TEPHRITIDAE)

(Nemartoda: Rhabditidae) have emerged as excellent insect biocontrol agents. Also it agree with other attempts concerning the infectivity of EPN on the peach fruit fly, Bactrocera zonata (Attala et al., 2002), the cucurbit fly, Dacus ciliatus (Fetoh and El-Gendi, 2006), peach fruit fly, Bactrocera zonata and the med fly Ceratitis capitata (Soliman, 2007 a\&b).

The non-feeding, third-stage infective juvenile of nematodes (IJs) is the only stage that survives outside of the host. The IJ carries cells of symbiotic bacteria in its intestine. When the IJ finds a suitable host, it invades and enters into the host's heamocel through the natural openings and releases the bacteria that kill the host within 48 hours. These bacteria produce antibodies that prevent other micro-organisms from colonizing the cadavers of host. Furthermore, serving as a food source for nematodes, the bacteria digest the host tissues, thereby providing suitable nutrients for nematodes growth and development (Ehlers, 2001).

Table 1. Effects of selected concentrations of the entomopathogenic nematodes on Bactrocera zonata and Dacus ciliatus larvae

\begin{tabular}{|c|l|c|c|c|}
\hline \multirow{2}{*}{$\begin{array}{c}\text { Concentration } \\
\mathrm{IJs} / \mathrm{cm}^{2}\end{array}$} & \multicolumn{2}{|c|}{ Bactrocera zonata } & \multicolumn{2}{c|}{ Dacus ciliatus } \\
\cline { 2 - 5 } & $\mathrm{Sc}$ & $\mathrm{Hb}$ & $\mathrm{Sc}$ & $\mathrm{Hb}$ \\
\hline 50 & $9.3(9-10) \mathrm{e}$ & $67.3(65-69) \mathrm{E}$ & $12.7(10-15) \mathrm{e}$ & $46.3(45-48) \mathrm{E}$ \\
\hline 100 & $14.7(13-16) \mathrm{d}$ & $79.7(78-81) \mathrm{D}$ & $20.2(19-21) \mathrm{d}$ & $72.7(70-75) \mathrm{D}$ \\
\hline 150 & $26.0(25-27) \mathrm{C}$ & $86.3(85-88) \mathrm{C}$ & $26.7(25-29) \mathrm{C}$ & $86.7(85-88) \mathrm{C}$ \\
\hline 200 & $37.7(36-39) \mathrm{b}$ & $94.7(93-96) \mathrm{B}$ & $37.7(35-40) \mathrm{b}$ & $98.0(96-99) \mathrm{B}$ \\
\hline 250 & $42.7(40-45) \mathrm{a}$ & $100(100-100) \mathrm{A}$ & $52.3(50-55) \mathrm{a}$ & $100(100-100) \mathrm{A}$ \\
\hline
\end{tabular}

The same letter in the same column is non-significant.

Table 2. Effects of selected concentrations of the entomopathogenic nematodes on Bactrocera zonata and Dacus ciliatus pupae

\begin{tabular}{|c|l|c|c|c|}
\hline \multirow{2}{*}{$\begin{array}{c}\text { Concentration } \\
\mathrm{IJs} / \mathrm{cm}^{2}\end{array}$} & \multicolumn{2}{|c|}{ Bactrocera zonata } & \multicolumn{2}{c|}{ Dacus ciliatus } \\
\cline { 2 - 5 } & \multicolumn{1}{|c|}{$\mathrm{Sc}$} & $\mathrm{Hb}$ & $\mathrm{Sc}$ & $\mathrm{Hb}$ \\
\hline 50 & $2.7(2-3) \mathrm{e}$ & $12.7(11-15) \mathrm{E}$ & $1.7(1-2) \mathrm{C}$ & $6.3(5-8) \mathrm{E}$ \\
\hline 100 & $9.0(8-10) \mathrm{d}$ & $20.3(18-23) \mathrm{D}$ & $4.0(3-5) \mathrm{d}$ & $8.7(7-10) \mathrm{D}$ \\
\hline 150 & $12.0(11-13) \mathrm{C}$ & $35.7(33-38) \mathrm{C}$ & $9.0(8-10) \mathrm{C}$ & $14.7(13-16) \mathrm{C}$ \\
\hline 200 & $21.7(20-23) \mathrm{b}$ & $47.7(54-50) \mathrm{B}$ & $17.1(15-20) \mathrm{b}$ & $25.0(22-28) \mathrm{B}$ \\
\hline 250 & $32.7(30-35) \mathrm{a}$ & $51.7(50-53) \mathrm{A}$ & $23.3(22-25) \mathrm{a}$ & $39.3(36-42) \mathrm{A}$ \\
\hline
\end{tabular}

The same letter in the same column is non-significant. 
Table 3. Effects of selected concentrations of the entomopathogenic nematodes on Bactrocera zonata and Dacus ciliatus adults.

\begin{tabular}{|c|c|c|c|c|}
\hline \multirow{2}{*}{$\begin{array}{c}\text { Concentration } \\
\mathrm{IJs} / \mathrm{cm}^{2}\end{array}$} & \multicolumn{2}{|c|}{ Bactrocera zonata } & \multicolumn{2}{c|}{ Dacus ciliatus } \\
\cline { 2 - 5 } & $\mathrm{Sc}$ & $\mathrm{Hb}$ & $\mathrm{Sc}$ & $\mathrm{Hb}$ \\
\hline 50 & $35.0(33-37) \mathrm{e}$ & $41.7(40-43) \mathrm{E}$ & $7.7(6-9) \mathrm{e}$ & $17.0(16-18) \mathrm{E}$ \\
\hline 100 & $39.7(38-41) \mathrm{d}$ & $51.7(50-53) \mathrm{D}$ & $13.7(12-15) \mathrm{d}$ & $25.3(23-28) \mathrm{D}$ \\
\hline 150 & $48.0(46-50) \mathrm{C}$ & $66.7(65-68) \mathrm{C}$ & $22.7(20-25) \mathrm{C}$ & $37.7(35-40) \mathrm{C}$ \\
\hline 200 & $62.3(60-65) \mathrm{b}$ & $73.3(72-75) \mathrm{B}$ & $28.3(27-30) \mathrm{b}$ & $43.7(42-45) \mathrm{B}$ \\
\hline 250 & $78.7(77-80) \mathrm{a}$ & $90.3(89-92) \mathrm{A}$ & $50.3(48-53) \mathrm{a}$ & $67.7(65-70) \mathrm{A}$ \\
\hline
\end{tabular}

The same letter in the same column is non-significant.

Table 4. The calculated LC50, LC90 and relative toxicological potency of the two species of nematodes on Bactrocera zonata and Dacus ciliatus larvae

\begin{tabular}{|c|c|c|c|c|c|c|c|c|}
\hline \multirow{2}{*}{ Treatment } & \multicolumn{4}{|c|}{ Bactrocera zonata } & \multicolumn{3}{c|}{ Dacus ciliatus } \\
\cline { 2 - 9 } & $\mathrm{LC}_{50}$ & $\mathrm{LC} 90$ & $\begin{array}{c}\text { Relative } \\
\text { potency }\end{array}$ & Slope & LC50 & LC90 & $\begin{array}{c}\text { Relative } \\
\text { Potency }\end{array}$ & Slope \\
\hline $\begin{array}{c}\text { Sc nematode } \\
\left(\mathrm{IJs} / \mathrm{cm}^{2}\right)\end{array}$ & 325.3 & 1718.6 & 1.1 & 1.7 & 286.2 & 1650.0 & 1 & 1.7 \\
\hline $\begin{array}{c}\mathrm{Hb} \text { nematode } \\
\left(\mathrm{IJs} / \mathrm{cm}^{2}\right)\end{array}$ & 28.8 & 167.2 & 1 & 1.6 & 56.7 & 156.1 & 1.9 & 2.9 \\
\hline
\end{tabular}

Table 5. The calculated LC50, LC90 and relative toxicological potency of the two species of nematodes on Bactrocera zonata and Dacus ciliatus pupae

\begin{tabular}{|c|c|c|c|c|c|c|c|c|}
\hline \multirow{2}{*}{ Treatment } & \multicolumn{4}{|c|}{ Bactrocera zonata } & \multicolumn{3}{c|}{ Dacus ciliatus } \\
\cline { 2 - 9 } & $\mathrm{LC}_{50}$ & $\mathrm{LC}_{90}$ & $\begin{array}{c}\text { Relative } \\
\text { potency }\end{array}$ & Slope & $\mathrm{LC}_{50}$ & $\mathrm{LC}_{90}$ & Relative & Slope \\
potency & \\
\hline $\begin{array}{c}\text { Sc nematode } \\
\left(\mathrm{IJs} / \mathrm{cm}^{2}\right)\end{array}$ & 540.2 & 1785.4 & 1 & 2.1 & 447.4 & 2009.8 & 1.2 & 2.3 \\
\hline $\begin{array}{c}\mathrm{Hb} \text { nematode } \\
\left(\mathrm{IJs} / \mathrm{cm}^{2}\right)\end{array}$ & 235.0 & 1167.0 & 1 & 1.8 & 420.8 & 1941.5 & 1.8 & 1.9 \\
\hline
\end{tabular}

Table 6. The calculated LC50, LC90 and relative toxicological potency of the two species of nematodes on Bactrocera zonata and Dacus ciliatus adults

\begin{tabular}{|c|c|c|c|c|c|c|c|c|}
\hline \multirow{2}{*}{ Treatment } & \multicolumn{4}{|c|}{ Bactrocera zonata } & \multicolumn{3}{c|}{ Dacus ciliatus } \\
\cline { 2 - 9 } & $\mathrm{LC}_{50}$ & $\mathrm{LC}_{90}$ & $\begin{array}{c}\text { Relative } \\
\text { potency }\end{array}$ & Slope & $\mathrm{LC}_{50}$ & $\mathrm{LC}_{90}$ & $\begin{array}{c}\text { Relative } \\
\text { potency }\end{array}$ & Slope \\
\hline $\begin{array}{c}\text { Sc nematode } \\
\left(\mathrm{IJs} / \mathrm{cm}^{2}\right)\end{array}$ & 116.8 & 319.3 & 1 & 1.5 & 261.6 & 375.0 & 2.7 & 2.0 \\
\hline $\begin{array}{c}\mathrm{Hb} \text { nematode } \\
\left(\mathrm{IJs} / \mathrm{cm}^{2}\right)\end{array}$ & 77.3 & 290.8 & 1 & 1.8 & 196.7 & 253.7 & 2.5 & 1.9 \\
\hline
\end{tabular}



THE PEACH FRUIT FLY, BACTROCERA ZONATA (SAUNDERS) AND THE CUCURBIT FRUIT FLY, DACUS CILIATUS (LOEW) (DIPTERA : TEPHRITIDAE)

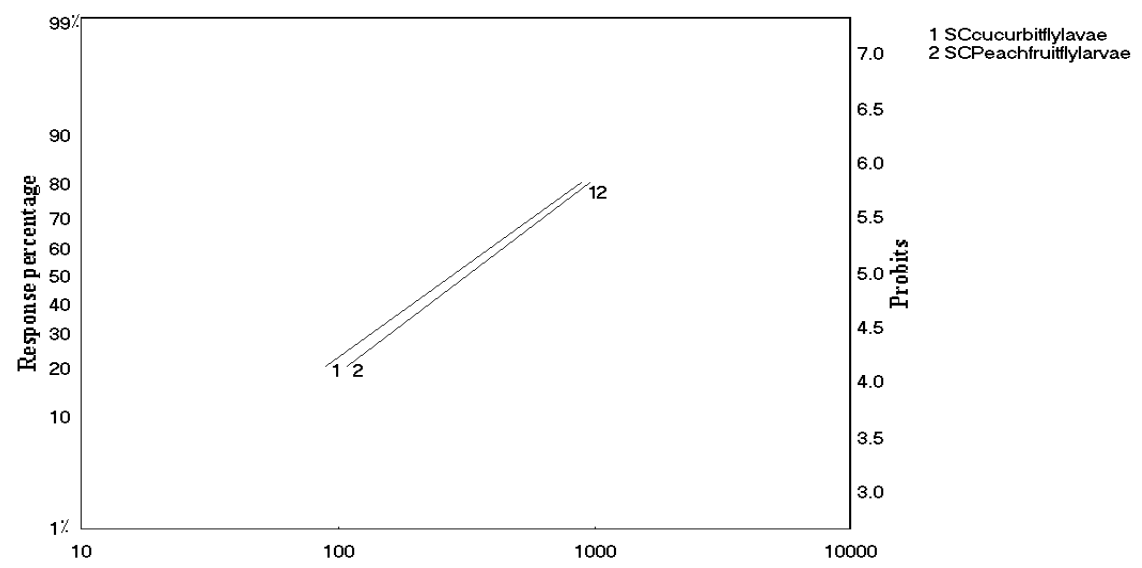

Fig. 1. Log-probity curve of percent of Sc entomopathogenic nematode on the peach fruit fly and cucurbit fly larvae

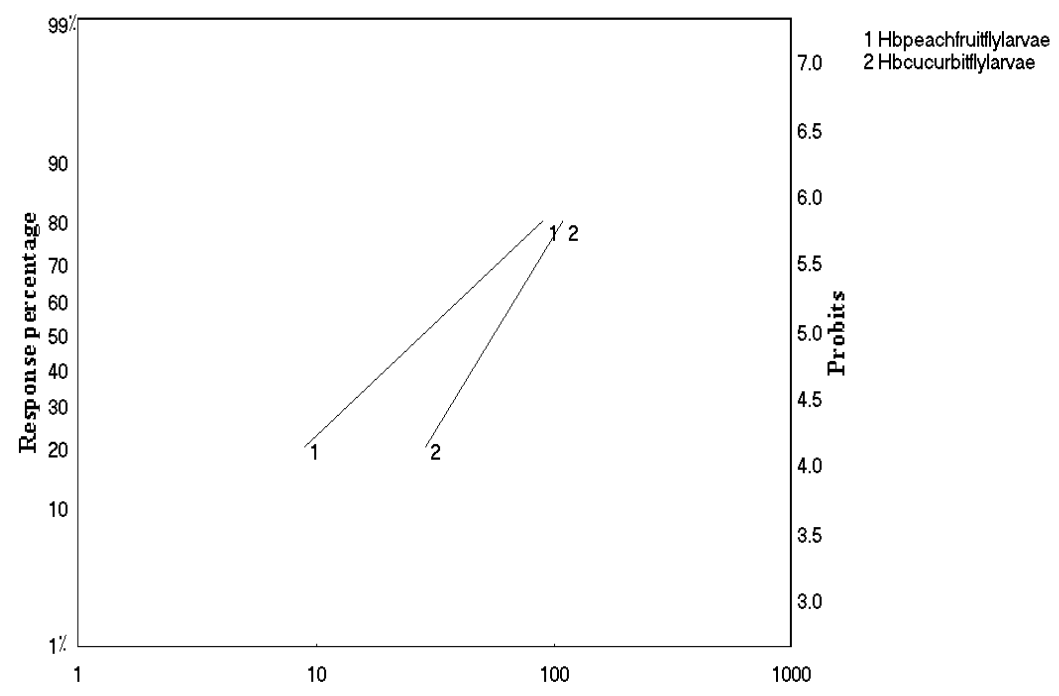

Fig. 2. Log-probity curve of percent of $\mathrm{Hb}$ entomopathogenic nematode on the peach fruit fly and cucurbit fly larvae 


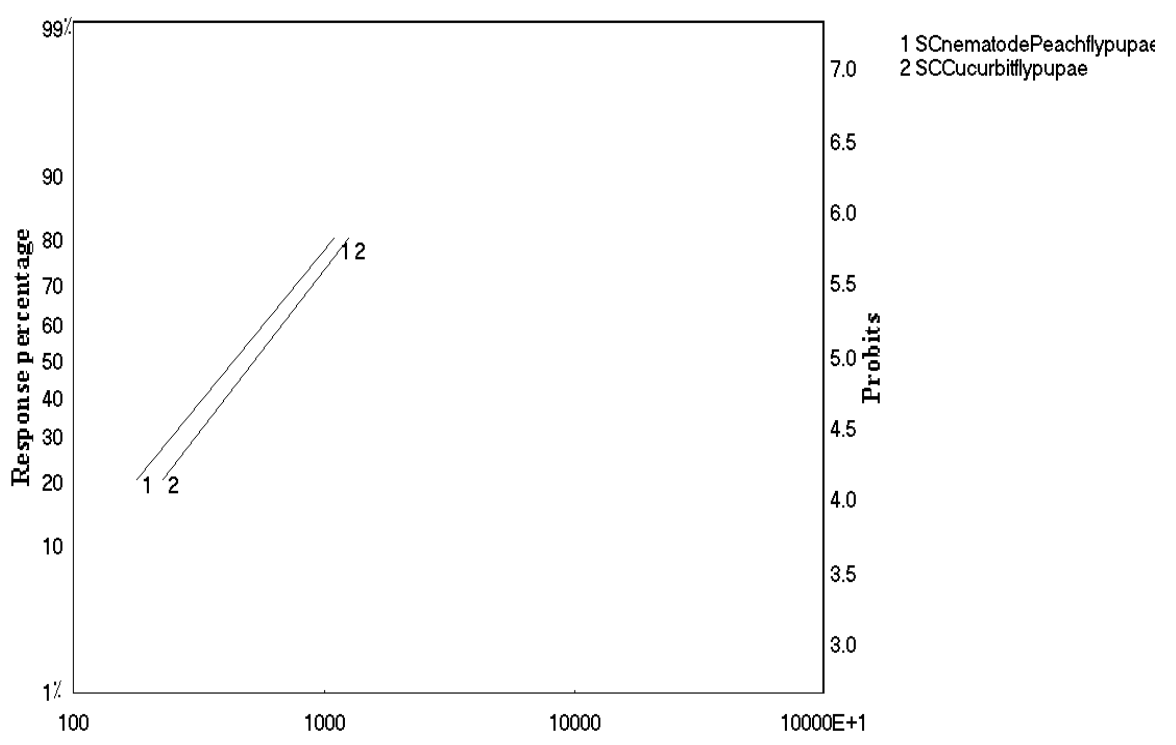

Fig. 3. Log-probity curve of percent of Sc entomopathogenic nematode on the peach fruit fly and cucurbit fly pupae

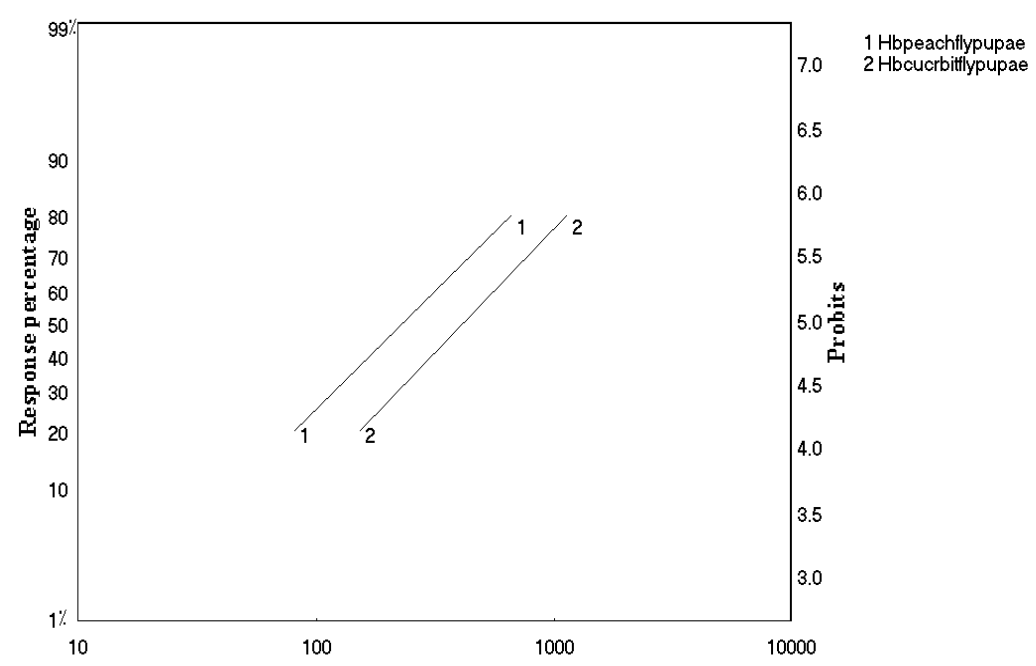

Fig. 4. Log-probity curve of percent of $\mathrm{Hb}$ entomopathogenic nematode on the peach fruit fly and cucurbit fly pupae 

THE PEACH FRUIT FLY, BACTROCERA ZONATA (SAUNDERS) AND THE CUCURBIT FRUIT FLY, DACUS CILIATUS (LOEW) (DIPTERA : TEPHRITIDAE)

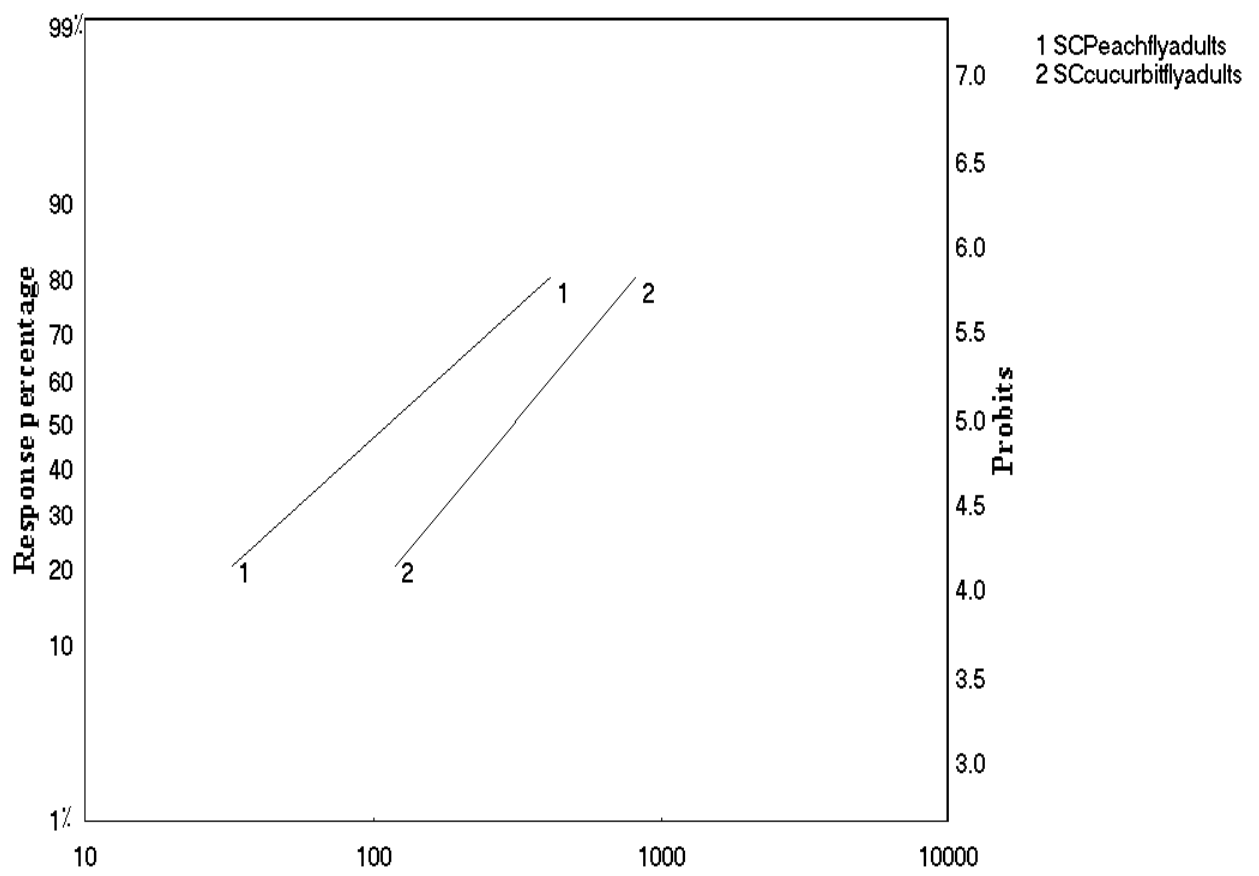

Fig. 5. Log-probity curve of percent of Sc entomopathogenic nematode on the peach fruit fly and cucurbit fly adults

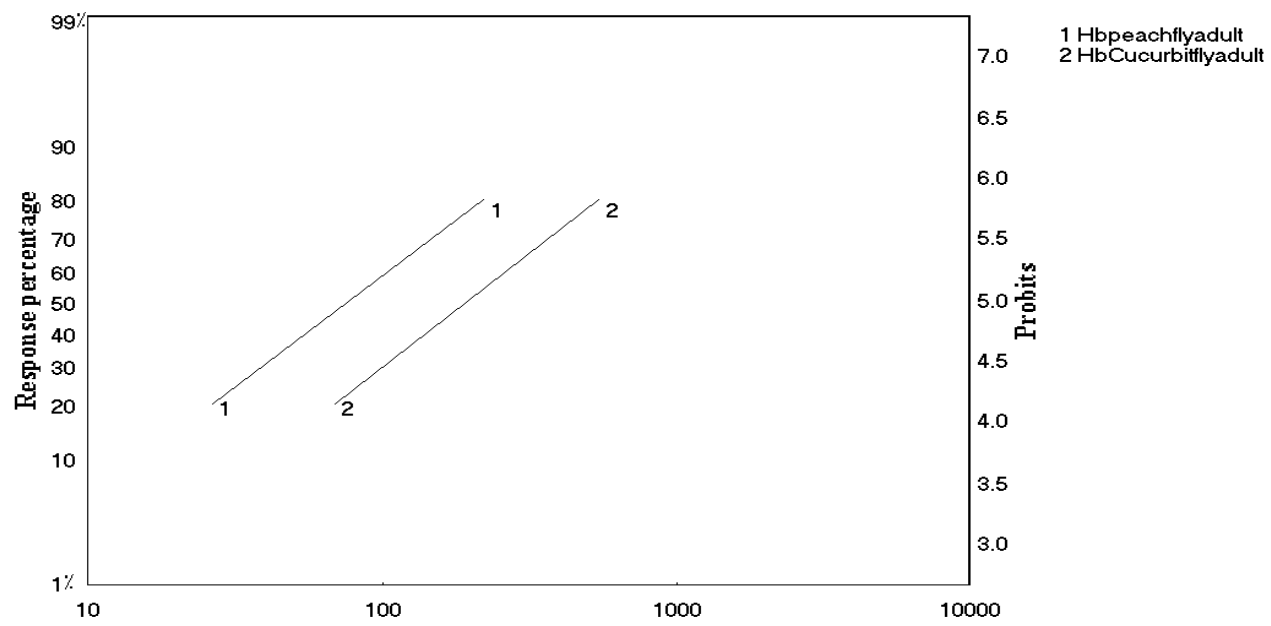

Fig. 6. Log-probity curve of percent of $\mathrm{Hb}$ entomopathogenic nematode on the peach fruit fly and cucurbit fly adults 
The previous studies indicated that larvae of the fruit flies were highly susceptible to EPN , but pupae were generally less susceptible to EPN (Gazit et al., 2000).

Fetoh and El-Gendi (2006) and Soliman (2007a) reported that EPN were effective on the newly formed pupae than aged pupae, and used EPN to control the adults of PFF and CFF. Soliman (2007a) used sugar solutions $1 \%$ and $4 \%$ mango, guava, orange juices, agar solution and a nematode- water suspensions to control both of the peach fruit fly and the med fly.

Wallace(1958) and Soliman (2007a) mentioned that carbon dioxide gas plays a role in EPN attraction to its host. Full grown larvae showed high activity after existing from their plant hosts searching for a suitable site to pupate. It was acceptable that this stage produces carbon dioxide gas therefore, high infection occurred by nematodes. Although the pupae were apparently less susceptible to nematodes infection than the full grown larvae, $\mathrm{Hb}$ infective juveniles were able to cause moderate pupal mortality rates at early pupal stages than Sc infective juveniles. This might be due to presence of the terminal tooth which was a discriminative feature of heterorhabditids that enable them to penetrate their host bodies through cuticle.

The obtained data in this offered work showed that $\mathrm{Hb}$ nematode was more effective than Sc nematode. It could be concluded that $\mathrm{Hb}$ nematode was the best candidate for control fruit flies as it caused high mortality to target pests. The high virulence of $\mathrm{Hb}$ nematode native isolates to the tested insects was unclear but may be able to be attributed to the rapid penetration in or rapid bacterial growth inside host's body and this in the agreement with Soliman (2007b). Toledo et al., (2006) used $\mathrm{Hb}$ nematode on Anastrepha ludens (Diptera: Tephritidae) and mentioned that $\mathrm{Hb}$ nematode caused high pathogenicity. Glazer (1992) stated that Steinernema carpocapsae All strains was less effective than Heterorhabditis bacteriophora HP88 when applied to different lepidopteron pests according to LD50 and LT 50 values. 


\section{REFERENCES}

1. Abbott, W.S. 1925. A method for computing the effectiveness of insecticides. J. Econ. Ent. 18: 265-267.

2. Attala, A., Fatima A. and M.A. Eweis. 2002. Preliminary investigation on the utilization of entomopathogenic nematodes as biological control agents against the peach fruit fly, Bactrocera zonata (Saunders) (Diptera: Tephritidae). Egyptian Journal of Agricultural Research, 80 (3): 1045-1053.

3. Azab, A. and T. Kira. 1954. Dacus ciliatus an important pest attacking cucurbitaceous plants in Upper Egypt. Soc. Foad $1^{\text {st }} d$ Ent., Bull.30:379-382.

4. Duncan, D. B. 1955. Multiple range and multiple F-tests. Biometric. 11:1-45.

5. Ehlers, R. U. 2001. Mass production of entomopathogenic nematodes for plant protection. Applied Micro. \& biotech. 56: 623-633.

6. Fetoh , B. E. A. and S. S. El-Gendi. 2006. Impact of entomopathogenic nematodes on different stages of the pumpkin fly, Dacu ciliatus as a new approach in its biological control. Fayoum J. Agric. Res.\&Dev. 20(2)19-25.

7. Finney, D. J. 1971. Probit analysis. $3^{\text {rd }}$ edition Cambridge Univ. Press Cambridge.

8. Gaugler, R. and Kaya, H. K. 1990. Entomopathogenic nematodes in biological control. CRC, Boca Raton, FL, USA.

9. Gazit, Y. Y., Y. Y. Rossler and I. Glazer. 2000. Evaluation of entomopathogenic nematodes for the control of Mediterranean fruit fly, Ceratitis capitata (Diptera: Tephritidae). Bio-control Sci. \& tech. 10:157-164.

10. Glazer, I. 1992. Invasion rate as a measure of infectivity of steinernematid and heterorhabditid nematodes to insects. Journal of Invertebrate Pathology. 59:90:94.

11. Kapoor, V.C. 1993. Indian fruit flies: (Insecta: Diptera: Tephritidae). New Delhi, India, Oxford \& IBH Publishing Co. Pvt. Ltd. India. 228 pp.

12. Kaya, H. K. and S. P. Stock. 1997. Techniques in insect nematology. In: LACEY, L.A. Manual of techniques in insect pathology, San Diego: Academic, 1997. p.281324.

13. Roessler, Y. 1989. Control, insecticides, insecticidal bait and cover sprays. Pages 329-336. In: Fruit Flies: their Biology, Natural Enemies and Control (Eds Robinson AS \& Hooper G), World Crop Pests 3 (B). Elsevier, Netherlands. 447 pp.

14. Shapiro, D. I. and E. E. Lewis. 1999. Comparison of entomopathogenic nematodes infectivity from infected hosts versus aqueous suspension. Environ. Entomol. 28: 907-911. 
15. Soliman, N. A. 2007a. Efficacy of the entomopathogenic nematodes Steinernema riobravis Cabanillas and Heterorhabditis bacterophora (Native strain) against the peach fruit fly, B. zonata and the Mediterranean fruit fly, C. capitata.Egypt. J. Biolo. Pest Control. 17(2):77-82.

16. Soliman , N. A. 2007b. Pathogenicity of the entomopathogenic nematodes to the peach fruit fly, B. zonata and the Mediterranean fruit fly, C. capitata.Egypt. J. Biolo. Pest Control. 17(2):121- 124.

17. Tanaka, N., R. Okumoto and D. L. Chambers. 1969. Low cost larval rearing medium for mass production of oriental and Mediterranean fruit flies. J, Econ. Entomol. 62:967-968.

18. Toledo, J., M. A. Rasgado, J. E. Ibarra, A. Gomez, P. Liedo and T. Williams. 2006. Infection of Anastrepha ludens (Diptera: Tephritidae). following soil application of Heterorhabditis bacterophora Poinar in a mango orchards. Ent. Exp. Appl. 119:155-162.

19. Wallace, H. R. 1958. Movement of eelworms. Ann. Appl. Ent., 46: 74-85. 


\section{التأثيرات الممرضة والمميتة للنيماتودا الممرضة للحشرات علي كل من ذبابة ثمار الخوخ وذبابة القرعيات}

$$
\begin{aligned}
& \text { بدر الصباح عبد المنعم فتوح' ، أحمد عبد الوهاب عبد الجواد² ، } \\
& \text { فوزي فائق شلبي² ، مصطفي فاروق عليمي } 1 \\
& \text { ' ' . معهز بحوث وقاية النباتات - مركز البحوث الزراعية - الدقي - جيزة }
\end{aligned}
$$

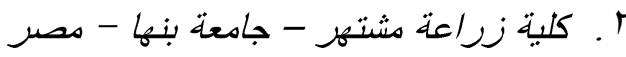

أجريت تجارب معملية لتقدير النأثيرات الممرضة و المميتة لنوعين من النيماتودا الممرضة

للحشرات من جنسي هيتيرور ابيدتيس وشتينرنيما علي يرقات كاملة النمو و عذارى حديثة التكون

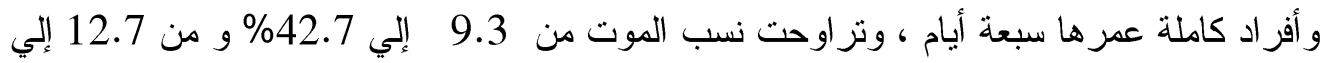

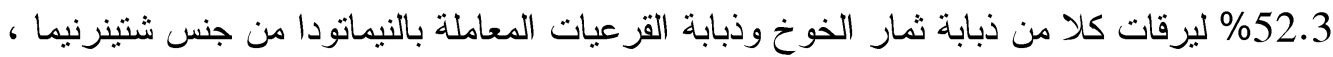
ومن 67.3 إلي 100\% و من 46.3 إلي 100\% ليرقات كلا من ذبابة ثمار الخوخ وذبابة القرعيات المعاملة بالنيماتودا من جنس هيتيرور ابيدتيس ، بينما كانت نسب الموت لعذارى ذبابة ثمار الخوخ

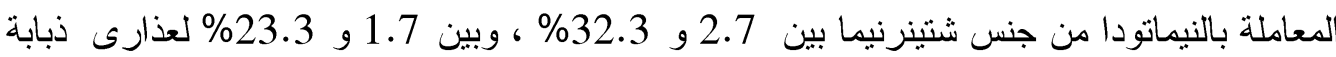

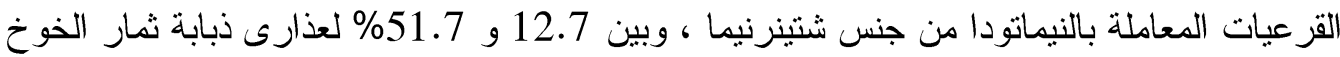

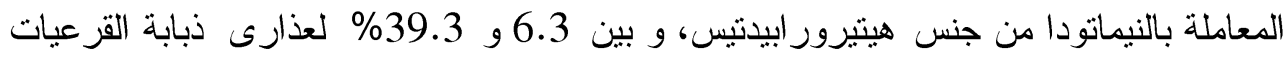
المعاملة بالنيماتودا من جنس هيتيرور ابيدتيس ، وتتوعت نسب الموت في الأفر اد الكاملة من 35.0

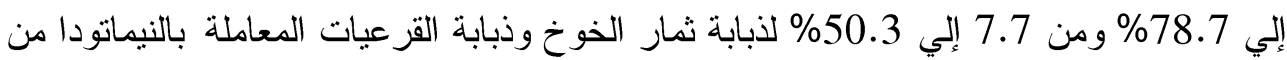

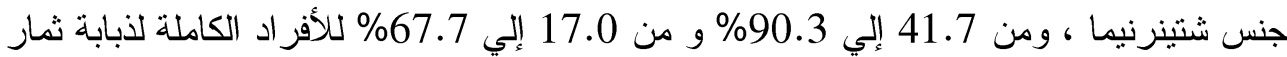
الخوخ وذبابة القرعيات المعاملة بالنيمانودا من جنس هيتيرور ابيدتيس علي التو الي، كما تم حساب قيم

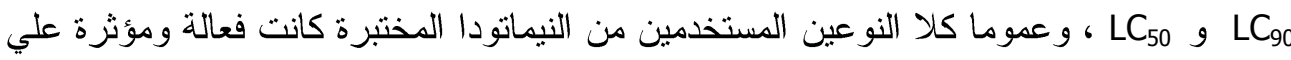
كل من ذبابة ثمار الخوخ وذبابة القرعيات وان كانت ذبابة ثمار الخوخ أكثر تأثر ا بالنيماتودا الممرضة للحشرات عن ذبابة القرعيات ، وكانت اليرقات و الأفر اد الكاملة أكثر حساسية للنيماتودابها الممرضة للحشر ات عن العذارى للذبابتين. 